\title{
Influence of Dietary Protein on Glomerular Filtration Before and After Bariatric Surgery: A Cohort Study
}

\author{
Allon N. Friedman, M.D. ${ }^{1}$, Sara K. Quinney, Ph.D. ${ }^{1,2}$, Margaret Inman, M.D. ${ }^{3}$, Samer G. \\ Mattar, M.D. ${ }^{4}$, Zak Shihabi, Ph.D. ${ }^{5}$, and Sharon Moe, M.D ${ }^{1,6}$ \\ ${ }^{1}$ Department of Medicine, Indiana University School of Medicine, Indianapolis, IN 46202 \\ ${ }^{2}$ Department of Obstetrics and Gynecology, Indiana University School of Medicine, Indianapolis, \\ IN 46202 \\ ${ }^{3}$ Meridian Surgical Group, Inc., Carmel, IN 46032 \\ ${ }^{4}$ Department of Surgery, Indiana University School of Medicine, Indianapolis, IN 46278 \\ ${ }^{5}$ Department of Pathology, Wake Forest University School of Medicine, Winston-Salem, NC \\ 27157 \\ ${ }^{6}$ Department of Medicine, Roudebush Veterans Affairs Medical Center, Indianapolis, IN 46202
}

\begin{abstract}
Background-Obesity-associated elevations in the glomerular filtration rate (GFR) are common and may play a role in the development of kidney disease, so identifying the underlying mechanism is important. We therefore studied whether reductions in dietary protein intake, which is known to modulate GFR, explain why the GFR falls after bariatric surgery-induced weight loss.
\end{abstract}

Study Design-Cohort study with participants as own controls.

Setting \& Participants-Eight severely obese patients with normal kidney function were recruited from bariatric surgery centers in Indianapolis, IN. All participants were placed on a fixed protein $(50 \mathrm{~g} / \mathrm{d})$ diet for one week period before and after a minimum of a 20-kg weight loss via bariatric surgery and were followed closely by dieticians for adherence.

Predictor-Ad lib versus low-protein diet before versus after bariatric surgery.

Outcome-Measured GFR, using repeated measures analysis, was used to estimate the independent effects of diet and surgery.

Measurement-GFR was measured using plasma iohexol clearance.

Results-A median of 32.9 (range, 19.5-54.4) kg was lost between the first pre-surgery visit and first post-surgery visit. Dietetic evaluations and urinary urea excretion confirmed that patients generally adhered to the study diet. GFR levels on an ad lib diet were significantly higher before compared to after surgery (GFR medians were 144 (range, 114-178) and 107 (range, 85-147) mL/

(C) 2013 The National Kidney Foundation, Inc. Published by Elsevier Inc. All rights reserved.

Address Correspondence to: Allon Friedman, M.D., 550 University Blvd., Suite 6100, Indianapolis, IN 46202, Tel: (317) 948-9419, Fax: (317) 944-4319 allfried@iu.edu.

Financial Disclosure: The authors declare that they have no other relevant financial interests.

Publisher's Disclaimer: This is a PDF file of an unedited manuscript that has been accepted for publication. As a service to our customers we are providing this early version of the manuscript. The manuscript will undergo copyediting, typesetting, and review of the resulting proof before it is published in its final citable form. Please note that during the production process errors may be discovered which could affect the content, and all legal disclaimers that apply to the journal pertain. 
$\min$, respectively; $\mathrm{P}=0.01)$. While bariatric surgery $(-26 \mathrm{ml} / \mathrm{min} ; \mathrm{P}=0.005)$ and dietary sodium intake ( $+7.5 \mathrm{ml} / \mathrm{min}$ per $100 \mathrm{mg}$ dietary sodium; $\mathrm{P}=0.001)$ both influenced GFR, consuming a low protein diet did not $(\mathrm{P}=0.7)$.

Limitations-Small sample size; mostly white females; possible lack of generalizability

Conclusions-The fall in GFR observed after bariatric surgery is explained at least in part by the effects of surgery and/or dietary sodium intake but not by low dietary protein consumption.

\section{Keywords}

obesity; bariatric surgery; glomerular filtration rate; glomerular hyperfiltration; protein; diet; kidney; renal function; weight reduction

The global obesity crisis shows little sign of relenting ${ }^{1}$. This has major implications for the field of nephrology inasmuch as obesity has been linked in a variety of experimental and observational settings to the development and progression of CKD ${ }^{2-6}$. A variety of putative mechanisms have been postulated to account for the obesity-CKD link. Among them is supranormal elevations in the glomerular filtration rate (GFR; so-called glomerular hyperfiltration), a frequent finding in obese individuals that in certain settings may lead to intraglomerular and systemic hypertension and ultimately kidney injury 7,8 .

The mechanisms underlying glomerular hyperfiltration are not fully understood though a relative afferent (versus efferent) vasodilation of the glomerular arteriole has been implicated ${ }^{9}$. While this process may be linked to the influence of excess adiposity via, for example, upregulation of the renin-aldosterone axis and tubuloglomerular feedback ${ }^{10}$, an alternative explanation involves the effects of dietary intake. Indeed, high protein diets consumed in the short or long term are also known to induce glomerular hyperfiltration ${ }^{11-14}$, and it is notable that obese persons consume more protein than do lean individuals ${ }^{15}$. Other nutrients, such as dietary sodium, may also influence renal hemodynamics 16 .

Weight reduction has been demonstrated to reverse the elevations in GFR ${ }^{17}$ and also protect against kidney disease ${ }^{18}$. Whether the reduction in the glomerular filtration rate (GFR) is attributable to shrinking adipose mass, a fall in dietary protein consumption, or other factors that occur in parallel with weight loss is unknown. Elucidating the mechanisms involved in glomerular hyperfiltration may help in developing strategies to reduce obesity-associated kidney injury. Thus, we performed an experiment to test the hypothesis that reductions in GFR observed after bariatric surgery are explained by lower post-surgical dietary protein consumption.

\section{METHODS}

\section{Participants}

Most of the participants in this study were part of a larger, previously published project that examined the relationship between GFR and protein consumption in obese patients 19,20. Obese individuals were recruited from bariatric surgery clinics and public advertisements in the Indianapolis, Indiana, area between 2004 and 2011. The relevant institutional review boards (study no. 0309-03) approved the protocol (ClinicalTrials.gov study number: NCT00244790), and all patients gave written informed consent after reviewing a written summary of the plan. The study adhered to the Declaration of Helsinki. A data safety and monitoring board oversaw the study. Inclusion criteria included age 18 or olderer, ability to give informed consent, a body mass index (BMI) of $30 \mathrm{~kg} / \mathrm{m}^{2}$ or higher, and planned bariatric surgery. Exclusion criteria included pregnancy, an iodine allergy, a diagnosis of 
diabetes mellitus, use of an angiotensin-converting enzyme (ACE) inhibitor or angiotensin receptor blocker (ARB), a serum creatinine level $>1.3 \mathrm{mg} / \mathrm{dl}$ for women and $>1.5 \mathrm{mg} / \mathrm{dl}$ for men, and dialysis dependency. Pregnancy was excluded by a urine pregnancy test on the day of study.

\section{Dietary Intervention}

The intervention was designed to study participants on a low protein dietary intervention before and after bariatric surgery. All studies were performed in the Indiana University General Clinical Research Center in a fasting state. Participants were studied prior to surgery while consuming an ad lib diet. They were then provided with seven days' worth of a low protein diet that consisted of $50 \mathrm{~g}$ of animal protein and $4 \mathrm{~g}$ sodium daily and isocaloric dietary content calculated using standard equations. The study diet was low protein because of the expectation that individuals would spontaneously lower their protein consumption after surgery. After one week on the study diet each participant returned to the research center to be studied again. An identical protocol was performed after bariatric surgery. The post-surgery low protein diet was the same as the pre-surgery diet with the exception of the sodium content, which was lowered to $2 \mathrm{~g}$ daily and caloric intake, which was set at $800 \mathrm{kcal}$ daily. These changes were made to make the diet palatable and tolerable in light of the severe dietary restrictions that bariatric surgery imposed. Thus, time points 1 and 2 occurred 1 week apart on an ad lib and low protein diet, respectively, prior to bariatric surgery. Time points 3 and 4 occurred 1 week apart on an ad lib and low protein diet, respectively, after bariatric surgery. Of note, the post-surgery visits were performed after a minimum of $20 \mathrm{~kg}$ was lost, an amount that was felt sufficient to see significant GFR changes based on our preliminary analyses. An Indiana University General Clinical Research Center dietitian using the University of Minnesota's Nutrition Data System for Research nutrient calculation software (www.ncc.umn.edu) developed the study diet while tailoring it as much as possible to the subject's dietary tastes. Meals were prepared and frozen in disposable containers that could subsequently be microwaved or heated in ovens at home. Subjects were carefully instructed to limit their dietary intake during the study period to study meals only and return any unfinished meals at the end of the study week. Dieticians contacted subjects by phone during the study intervention period to assess dietary adherence and help resolve any diet-related problems. They also estimated dietary nonadherence at the end of the study by quantifying any unfinished meals (patients were asked to bring in all unfinished meals) and performing a 24-hour dietary recall interview.

\section{Measurements}

GFR was calculated from plasma iohexol (Omnipaque-300; GE Healthcare, Piscataway, NJ) clearance. Plasma was isolated and stored at $-80^{\circ} \mathrm{C}$ until measured by capillary electrophoresis using a Model $2050 \mathrm{CE}$ instrument (Beckman Instruments, Palo Alto, CA, USA) as previously reported ${ }^{19}$ or HPLC (Agilent 1100, Santa Clara, CA) with UV detection. Individual iohexol clearances $(\mathrm{ml} / \mathrm{min})$ were estimated using standard noncompartmental methods with iohexol clearance equivalent to dose divided by the area under the plasma concentration-time curve from time zero through infinity. In cases where only two plasma concentrations were available per individual, population pharmacokinetic methods were used as previously described ${ }^{20}$. Body mass index (BMI) and body surface area (BSA) ${ }^{21}$ were calculated during each visit from measured weight and height while wearing a hospital gown and no shoes. The average of two blood pressures taken while seated and separated by a five minute interval was used. Serum creatinine was measured using by the Roche/Hitachi Creatinine Plus enzymatic assay (Roche Diagnostics, Basel Switzerland) calibrated to an IDMS method. Measurements of 24-hour urine creatinine, sodium, potassium, and urea were performed using standard laboratory techniques. One 
gram of urinary urea excretion was considered to be the equivalent of $6.25 \mathrm{~g}$ dietary protein $^{22}$.

\section{Statistical Methods}

The study's primary aim was to determine the effect of weight reduction on GFR after controlling for dietary protein consumption, the working hypothesis being that the reduction in GFR observed after weight loss would disappear if protein intake was fixed. Subject demographic information and baseline characteristics were summarized by median (range) or frequency for continuous variables and categorical variables, respectively. Changes in variables were measured using the Wilcoxon signed rank test because the normality assumption was violated. In order to test the effects of low protein diet on changes in GFR while controlling for bariatric surgery and urine sodium levels, we used a repeated measures analysis of covariance model. All statistical tests were performed at a two-sided 5\% significant level using the IBM SPSS Statistics 20 software package (Armonk, NY), or SAS, version 9.3 (SAS Institute Inc, Cary, North Carolina) and R statistical software, version 2.15 (R Foundation for Statistical Computing).

\section{RESULTS}

Sixteen persons were enrolled for the study, but eight did not complete the study protocol for various reasons (withdrew consent, 4; pregnant, 1; nonadherent to diet, 3). The individuals who dropped out were similar to the eight obese participants in terms of age (median, 44 [range, 22-51] years), gender (75\% female), and race (75\% white). The remaining eight severely obese participants were primarily white and female with fasting glucose and blood pressure levels that were in the normal range or at most mildly elevated (Table 1). Serum creatinine levels were also normal. All the participants underwent a Rouxen-Y gastric bypass except one, who underwent a vertical sleeve gastrectomy. A median of 32.9 (range, 19.5-54.4) $\mathrm{kg}$ was lost between the first pre-surgery visit and first post-surgery visit (median time elapsed, 234 [range, 103-614] days).

Based on the 24 hour urine collection data shown in Table 2, median baseline ad lib intake was approximately $2.2 \mathrm{~L}$ of fluid, $10 \mathrm{~g}$ of sodium, $2 \mathrm{~g}$ of potassium, and $75 \mathrm{~g}$ of protein. All of these dropped substantially after surgery including protein consumption, which fell roughly by half. Median protein consumption was not different on the low protein study diet pre- versus post-surgery ( $\mathrm{P}$ for difference $=0.9$ ) and was close to the protein allotment of 50 $\mathrm{g}$ daily provided in the study regimen (pre-surgery, $56 \mathrm{~g}$; post-surgery, $44 \mathrm{~g}$ ). Sodium and potassium intake was also similar at these time points (Table 2).

The GFR levels at each study time point are shown in Figure 1. The GFR levels were supranormal (i.e. $>120 \mathrm{ml} / \mathrm{min}$ ) in most subjects prior to surgery ${ }^{23}$ and then dropped after surgery. There was no significant difference in the response to the diet after versus before surgery $(\mathrm{P}=0.2)$. As shown in Table 3 , bariatric surgery and dietary sodium were each independently associated with changes in GFR, while a low protein diet was not.

\section{DISCUSSION}

Our study was designed to determine whether reduced protein consumption explains the reduction in GFR that is consistently observed after large weight reduction. To answer this question we used a model of bariatric surgery, the most rapid and effective weight loss strategy currently available. We found that while surgery and dietary sodium intake influenced GFR levels, consumption of a low protein diet did not. 
Elucidation of the mechanisms underlying the glomerular hyperfiltration of obesity is expected to advance our understanding of how obesity influences kidney health. Based on the well documented concept that dietary protein intake influences kidney hemodynamics, a topic previously reviewed by us and others in detail ${ }^{14,24}$, it is certainly plausible that dietary protein could play an important, and possibly central, role in mediating GFR during weight loss. This is especially true in patients undergoing bariatric surgery, a population from which nearly all of the rigorous human data on the kidney hemodynamic effects of weight loss have been derived. Bariatric surgery patients have ample reason to lower protein intake after surgery due to overall reductions in food intake from an anatomically restricted gastrointestinal tract and more specifically protein intolerance ${ }^{25}$. This effect was observed in our study cohort, where the median spontaneous intake of dietary protein dropped significantly by half after surgery (Table 2 ).

Despite major efforts in recent decades to identify exactly how protein feeding regulates kidney hemodynamics, the mechanisms are still not entirely clear ${ }^{24}$. Hypothesized mechanisms include amino acids as metabolic substrates for the changes; local or circulating humoral factors released by the stimulus of amino acids; and intrinsic kidney mechanisms like tubuloglomerular feedback. Perhaps the most consistent and cohesive model involves the latter mechanism, which can be stimulated by proximal tubular reabsorption of amino acids (and sodium), leading to upregulation of tubuloglomerular feedback, subsequent afferent arteriolar dilatation, and ultimately an increase in GFR and renal plasma flow. Of note, tubuloglomerular feedback is also currently believed to play a role in the glomerular hyperfiltration observed in obesity ${ }^{10}$.

In our study we controlled for protein consumption before and after surgery by fixing dietary protein intake at $50 \mathrm{~g}$ daily. Despite overall adherence to the study diet as confirmed by urinary urea nitrogen excretion, consuming a low protein diet did not independently influence GFR in the study participants. This finding demonstrates that ad lib reductions in dietary protein consumed after surgery does not explain why GFR falls after surgical weight loss. This result is consistent with our previous report indicating that high dietary protein intake is unlikely to explain the supranormal elevations in GFR seen in individuals with obesity ${ }^{19}$. This being the case, what other factors could possibly mediate the reduction in GFR that is seen in obese persons or animals that lose weight?

In addressing this question we should consider the other major macronutrient components carbohydrates and fat as well as dietary sodium intake. In studies of nonobese animals, carbohydrates have relatively minimal effect on GFR as compared to protein ${ }^{26,27}$ while the isolated effect of dietary fat on GFR has not been well studied. Interestingly, increased caloric intake leading to obesity has been demonstrated to increase GFR independent of protein consumption. Henegar et al ${ }^{5}$ studied the effects of the development of obesity on kidney hemodynamics and structure by randomizing healthy dogs to a regular diet versus one supplemented with beef fat. By seven to nine weeks the fat-supplemented dogs weighed significantly more and had a higher GFR (by 45\%) and renal plasma flow (by 75\%) than the lean dogs. Throughout the study dietary protein and sodium were held constant between the two groups. Studies such as this and others finding no independent effect of macronutrients on GFR ${ }^{28}$ support the contention that weight gain itself leading to obesity promotes an increase in GFR and that the source of the calories is of lesser importance. One possible explanatory mechanism involves upregulation of the renin-aldosterone axis that is observed with weight gain ${ }^{29}$. The resultant increase in proximal tubular sodium reabsorption would both expand the intravascular volume and stimulate tubuloglomerular feedback, with the result being a higher GFR. Weight reduction would be expected to reverse this process ${ }^{29}$. Preliminary findings that angiotensin-converting enzyme inhibition disproportionately benefits obese individuals with proteinuric kidney disease (as compared to leaner patients) 
support an active role for the renin-aldosterone axis in the pathophysiology of obesity ${ }^{30}$. Our finding that dietary sodium was independently associated with increases in GFR is consistent with this line of thinking. In fact, others have also observed such a phenomenon in obese individuals ${ }^{16}$. The effects of bariatric surgery on GFR may not simply be through downregulation of the renin-aldosterone axis but also through changes in gut peptides that mediate renal hemodynamics ${ }^{31}$, a field that needs further elucidation.

A strength of our mechanistic study is that it was successfully conducted using a challenging dietary intervention pre- and post-bariatric surgery in a cohort of individuals whose severe obesity is indicative of their difficulty in following restrictive diets. The time required to complete the study attest to the challenge of the task. Adherence to the fixed protein diet was confirmed after careful evaluation with study dieticians in conjunction with 24-hour urine collections. Our study also has limitations. The study cohort was modest in size despite efforts to avoid dropouts. Nevertheless, were able to show several important statistically significant relationships. While we cannot exclude the possibility that nonsignificant results would have been statistically significant in a larger cohort, the study's main focus (i.e. effects of low protein diet) had a $\mathrm{P}$ value that was well out of range of statistical significance. The study also focused specifically on the independent effect of dietary protein so the influence of carbohydrates and fat were not explored. The study was comprised primarily of white females, although there are no reports of sex or race disparities in the kidney's response to dietary protein or weight loss. In addition, the study used bariatric surgery to induce weight loss. While it is possible that large weight reduction from nonsurgical methods could have differing effects, such a study has not yet been performed and our findings are consistent with previous findings in animals ${ }^{18}$. We cannot definitively assume that surgery-related metabolic effects did not influence the findings because the post-surgery study time points were not fixed, though all subjects had fully recovered from the surgery by the time they were studied. Finally, we measured GFR in $\mathrm{ml} / \mathrm{min}$ rather than indexing to body surface area $\left(\mathrm{ml} / \mathrm{min} / 1.73 \mathrm{~m}^{2}\right)$. This was done because of the pitfalls of using indexed GFRs in obese persons and when studying changes within individuals 32,33 .

In summary, the fall in GFR observed after bariatric surgery can be explained at least in part by the effects of surgery and/or dietary sodium intake but not by low dietary protein consumption.

\section{Acknowledgments}

We thank Laurie Trevino, MS, RD, CCRC, and Cheryl Armstrong, PhD, MBA, RD, who provided invaluable nutrition support.

Support: This study was supported by the National Institutes of Health (grant 5K23RR019615), Dialysis Clinics Inc, and the Indiana Clinical and Translational Sciences Institute (grant TR000006).

\section{References}

1. Malik VS, Willett WC, Hu FB. Global obesity: trends, risk factors and policy implications. Nature reviews Endocrinology. 2013; 9(1):13-27.

2. Kambham N, Markowitz GS, Valeri AM, Lin J, D’Agati VD. Obesity-related glomerulopathy: an emerging epidemic. Kidney Int. 2001; 59(4):1498-1509. [PubMed: 11260414]

3. Praga M, Hernandez E, Morales E, et al. Clinical features and long-term outcome of obesityassociated focal segmental glomerulosclerosis. Nephrol Dial Transplant. 2001; 16(9):1790-1798. [PubMed: 11522860]

4. Chertow GM, Hsu CY, Johansen KL. The enlarging body of evidence: obesity and chronic kidney disease. J Am Soc Nephrol. 2006; 17(6):1501-1502. [PubMed: 16672317] 
5. Henegar JR, Bigler SA, Henegar LK, Tyagi SC, Hall JE. Functional and structural changes in the kidney in the early stages of obesity. J Am Soc Nephrol. 2001; 12(6):1211-1217. [PubMed: 11373344]

6. Hsu CY, McCulloch CE, Iribarren C, Darbinian J, Go AS. Body mass index and risk for end-stage renal disease. Ann Intern Med. 2006; 144(1):21-28. [PubMed: 16389251]

7. Brenner BM, Lawler EV, Mackenzie HS. The hyperfiltration theory: a paradigm shift in nephrology. Kidney Int. 1996; 49(6):1774-1777. [PubMed: 8743495]

8. Griffin KA, Kramer H, Bidani AK. Adverse renal consequences of obesity. Am J Physiol Renal Physiol. 2008; 294(4):F685-696. [PubMed: 18234955]

9. Chagnac A, Weinstein T, Korzets A, Ramadan E, Hirsch J, Gafter U. Glomerular hemodynamics in severe obesity. Am J Physiol Renal Physiol. 2000; 278(5):F817-822. [PubMed: 10807594]

10. Chagnac A, Herman M, Zingerman B, et al. Obesity-induced glomerular hyperfiltration: its involvement in the pathogenesis of tubular sodium reabsorption. Nephrol Dial Transplant. 2008; 23(12):3946-3952. [PubMed: 18622024]

11. Chan AY, Cheng ML, Keil LC, Myers BD. Functional response of healthy and diseased glomeruli to a large, protein-rich meal. J Clin Invest. 1988; 81(1):245-254. [PubMed: 3275694]

12. Solling K, Christensen CK, Solling J, Christiansen JS, Mogensen CE. Effect on renal haemodynamics, glomerular filtration rate and albumin excretion of high oral protein load. Scand J Clin Lab Invest. 1986; 46(4):351-357. [PubMed: 3523737]

13. Brandle E, Sieberth HG, Hautmann RE. Effect of chronic dietary protein intake on the renal function in healthy subjects. Eur J Clin Nutr. 1996; 50(11):734-740. [PubMed: 8933120]

14. Friedman AN. High-protein diets: potential effects on the kidney in renal health and disease. Am J Kidney Dis. 2004; 44(6):950-962. [PubMed: 15558517]

15. Andersson I, Rossner S. The Gustaf study: repeated, telephone-administered 24-hour dietary recalls of obese and normal-weight men--energy and macronutrient intake and distribution over the days of the week. J Am Diet Assoc. 1996; 96(7):686-692. [PubMed: 8675912]

16. Krikken JA, Lely AT, Bakker SJ, Navis G. The effect of a shift in sodium intake on renal hemodynamics is determined by body mass index in healthy young men. Kidney Int. 2007; 71(3): 260-265. [PubMed: 17091123]

17. Chagnac A, Weinstein T, Herman M, Hirsh J, Gafter U, Ori Y. The effects of weight loss on renal function in patients with severe obesity. J Am Soc Nephrol. 2003; 14(6):1480-1486. [PubMed: 12761248]

18. Maddox DA, Alavi FK, Santella RN, Zawada ET Jr. Prevention of obesity-linked renal disease: age-dependent effects of dietary food restriction. Kidney Int. 2002; 62(1):208-219. [PubMed: 12081580]

19. Friedman AN, Yu Z, Juliar BE, et al. Independent influence of dietary protein on markers of kidney function and disease in obesity. Kidney Int. 2010; 78:693-697. [PubMed: 20664561]

20. Friedman AN, Strother M, Quinney SK, et al. Measuring the Glomerular Filtration Rate in Obese Individuals without Overt Kidney Disease. Nephron Clin Pract. 2010; 116(3):c224-c234. [PubMed: 20606483]

21. DuBois D, DuBois E. A forumla to estimate the approximate surface area if height and weight be known. Arch Intern Med. 1916; 17:863-871.

22. Matthews, D. Modern Nutrition in Health and Disease. Lippincott Williams \& Wilkins; 1999.

23. Helal I, Fick-Brosnahan GM, Reed-Gitomer B, Schrier RW. Glomerular hyperfiltration: definitions, mechanisms and clinical implications. Nature reviews Nephrology. 2012; 8(5):293300.

24. Woods LL. Mechanisms of renal hemodynamic regulation in response to protein feeding. Kidney Int. 1993; 44(4):659-675. [PubMed: 8258943]

25. Moize V, Geliebter A, Gluck ME, et al. Obese patients have inadequate protein intake related to protein intolerance up to 1 year following Roux-en-Y gastric bypass. Obes Surg. 2003; 13(1):2328. [PubMed: 12630609]

26. Pitts R. The effects of infusing glycin and of varying the dietary protein intake on renal hemodynamics in the dog. Am J Physiol. 1944; 142:355-365. 
27. Shannon J, Jolliffe N, Smith H. The excretion of urine in the dog. IV. The effect of maintenance diet, feeding, etc., upon the quantity of glomerular filtrate. Am J Physiol. 1932; 101:625-638.

28. Jesudason DR, Pedersen E, Clifton PM. Weight-loss diets in people with type 2 diabetes and renal disease: a randomized controlled trial of the effect of different dietary protein amounts. Am J Clin Nutr. 2013; 98(2):494-501. [PubMed: 23719550]

29. Tuck ML, Sowers J, Dornfeld L, Kledzik G, Maxwell M. The effect of weight reduction on blood pressure, plasma renin activity, and plasma aldosterone levels in obese patients. N Engl J Med. 1981; 304(16):930-933. [PubMed: 7010165]

30. Mallamaci F, Ruggenenti P, Perna A, et al. ACE inhibition is renoprotective among obese patients with proteinuria. J Am Soc Nephrol. 2011; 22(6):1122-1128. [PubMed: 21527660]

31. Michell AR, Debnam ES, Unwin RJ. Regulation of renal function by the gastrointestinal tract: potential role of gut-derived peptides and hormones. Annual review of physiology. 2008; 70:379403.

32. Friedman A. The importance of considering metabolism when indexing the glomerular filtration rate. Am J Kidney Dis. 2010; 56:1218. [PubMed: 21094916]

33. Delanaye P, Radermecker RP, Rorive M, Depas G, Krzesinski JM. Indexing glomerular filtration rate for body surface area in obese patients is misleading: concept and example. Nephrol Dial Transplant. 2005; 20(10):2024-2028. [PubMed: 16030047] 


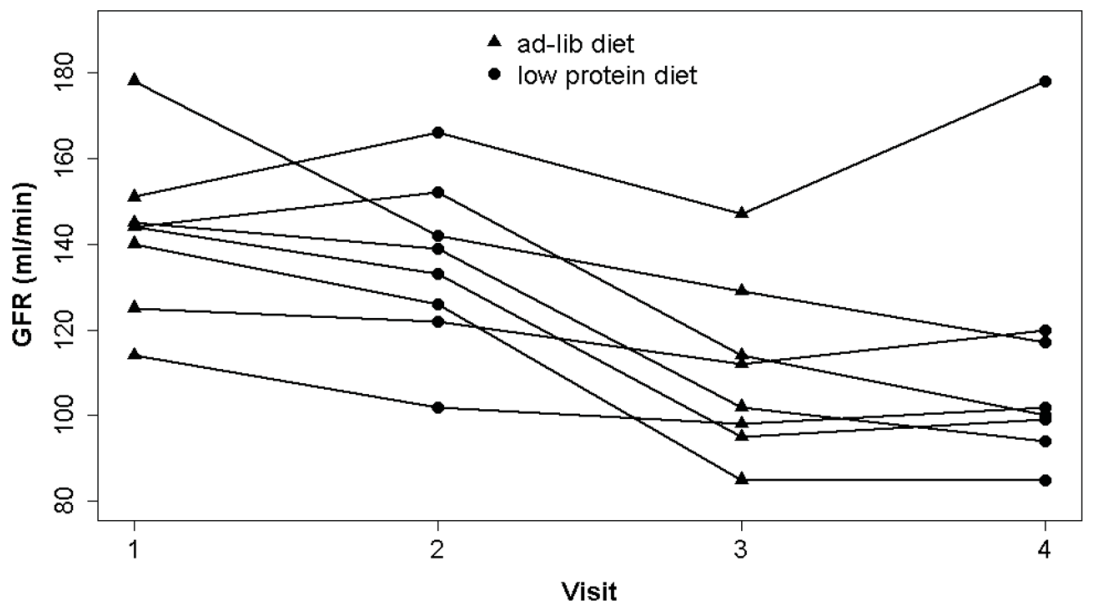

Figure 1.

GFR by study visit. Visit 1, ad lib diet pre surgery; Visit 2, low protein diet pre-surgery; Visit 3, ad lib diet post-surgery; Visit 4, low protein diet post-surgery. 


\section{Table 1}

Participant Characteristics at Baseline and After Surgery

\begin{tabular}{|l|c|c|}
\hline & Baseline & Postsurgery \\
\hline Age $(\mathrm{y})$ & $48(31,58)$ & -- \\
\hline Female sex & $7 / 8(88)$ & -- \\
\hline White race & $7 / 8(88)$ & -- \\
\hline Weight $(\mathrm{kg})$ & $125.5(105.1,196.2)$ & $81.1(70,158.2)$ \\
\hline Height $(\mathrm{cm})$ & $164(156,189)$ & -- \\
\hline Body mass index $\left(\mathrm{kg} / \mathrm{m}^{2}\right)$ & $45.2(39.8,64.7)$ & $30.9(25.9,44.9)$ \\
\hline Body surface area $\left(\mathrm{m}^{2}\right)$ & $2.28(2.02,3.03)$ & $1.88(1.76,2.76)$ \\
\hline Systolic blood pressure $(\mathrm{mm} \mathrm{Hg})$ & $137(115,154)$ & $134(103,150)$ \\
\hline Diastolic blood pressure $(\mathrm{mm} \mathrm{Hg})$ & $82(68,96)$ & $76(64,92)$ \\
\hline Serum creatinine $(\mathrm{mg} / \mathrm{dl})$ & $0.8(0.6,1.0)$ & $0.7(0.5,0.8)$ \\
\hline Fasting plasma glucose $(\mathrm{mg} / \mathrm{dl})$ & $90(71,120)$ & $81(62,97)$ \\
\hline
\end{tabular}

Note: Values for categorical variables are given as $\mathrm{n} / \mathrm{N}$ (percentage); values for continuous variables are given as median [range]. Conversion factors for units: creatinine in $\mathrm{mg} / \mathrm{dL}$ to $\mu \mathrm{mol} / \mathrm{L}, \times 88.4$; glucose in $\mathrm{mg} / \mathrm{dL}$ to $\mathrm{mmol} / \mathrm{L}, \times 0.05551$. 


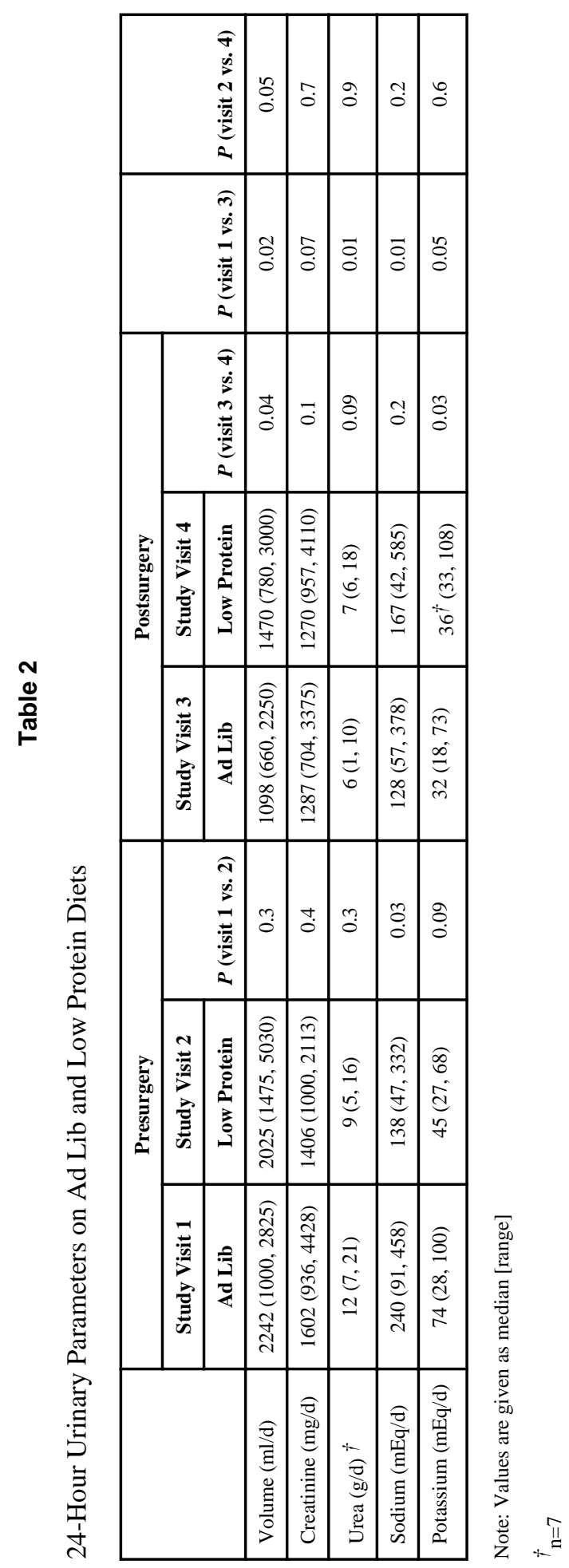

Am J Kidney Dis. Author manuscript; available in PMC 2015 April 01. 
Table 3

Independent Influence of Surgery and Diet on GFR

\begin{tabular}{|l|c|c|}
\hline Variable & Effect on GFR (ml/min) & P \\
\hline Surgery (post vs. pre) & $-26 \pm 7$ & 0.005 \\
\hline Diet (low protein vs. ad lib) & $-1.8 \pm 5$ & 0.7 \\
\hline Urinary sodium (per 100-mg greater) & $+7.4 \pm 1.4$ & 0.001 \\
\hline
\end{tabular}

Note: Values are given as mean \pm standard error.

GFR, glomerular filtration rate. 